\title{
TÜRKIYYE'NIN KARAYOLU POLITIIKASININ ÖRGÜTSEL BOYUTU: KARAYOLLARI GENEL MÜDÜRLÜĞÜNÜN KURUMSAL KAPASİTESİ ÜZERİNE BİR ÇÖZÜMLEME
}

\section{The Organizational Dimension of Turkey's Highway Policy: An Analysis of the Institutional Capacity of the General Directorate of Highways}

\author{
İbrahim ARAP*
}

Geliş: 18.08.2020/ Kabul: 02.12.2020

DOI: $10.33399 /$ biibfad.782181

Öz

Ulaştırma ekonomik, sosyal, kültürel ve askeri faaliyetler açısından yaşamsal önemdedir. Her ülke tarihsel-coğrafi koşulları ile sosyo-ekonomik durumuna göre ulaştırma türleri arasında bir bileşim oluşturmuştur. Türkiye'de yolcu ve yük ulaştırmasında ağırlık karayolundadır. Bu çalışmanın amacı, karayolu ulaştırma hizmetinde ana aktör olan Karayolları Genel Müdürlügüünun (KGM) bu görevini yapısal ve işleyişsel olarak ne ölçüde yerine getirdiğini, bir başka deyişle kurumsal kapasitesini değerlendirmektir. Çalışmada örgütün, kurumsal kapasitesi ile ilgili değerlendirmeler içeren dört stratejik planı karşılaştırmalı olarak incelenmektedir. Elde edilen temel bulguya göre KGM'nin kurumsal kapasitesi görevlerinin yüküyle orantılı değildir. Kurumsal kapasiteye ilişkin sorunlar bilinmekle birlikte sorunların giderilmesine yönelik önlem ve çabalar sınırlıdır, yetersiz kalmaktadır. Sonuç olarak, önümüzdeki yıllarda iç ve dış nedenlerle ulaştırmada karayolu ağırlıklı politika sürdürülecektir. $\mathrm{Bu}$ nedenle karayolu hizmetlerinin niteliğinin artırılması için KGM'nin kurumsal kapasitesinin geliştirilmesine yönelik çabalara yenilerinin eklenerek sürdürülmesi önem taşımaktadır.

Anahtar Kelimeler: Ulaştırma, karayolları genel müdürlüğü, kapasite, kurumsal kapasite, stratejik planlama.

Jel Kodlar1: H11; H83; D73.

* Doç. Dr., Dokuz Eylül Üniversitesi, İktisadi ve İdari Bilimler Fakültesi, Kamu Yönetimi Bölümü, ibrahim.arap@deu.edu.tr, ORCID: https://orcid.org/0000-00015890-5927 


\begin{abstract}
Transportation bears critical importance for economic, social, cultural, and military activities. Depending on its historical and geographical circumstances and its socioeconomic status, every country develops its own combination of modes of transportation. In Turkey, the largest share of the weight in passenger and cargo transportation is assumed by highways. The purpose of this paper is to evaluate to what extent the General Directorate of Highways (the GDH), the main actor responsible for highway transportation services, can fulfill this mission structurally and operationally; in other words, to assess its institutional capacity. The study reviews and contrasts four strategic plans involving assessments of the organization's institutional capacity. The main finding obtained is that the institutional capacity of the GDH is not proportional to its duty load. While the issues concerning institutional capacity are well-known, the measures and efforts to eliminate them are limited and remain insufficient. It is concluded that due to a number of internal and external reasons, the policies that prioritize highways will be sustained in the years to come. In order to increase the quality of highway services, it is therefore crucial to enrich and add to the efforts that aim to improve the institutional capacity of the GDH.
\end{abstract}

Keywords: Transportation, general directorate of highways, capacity, institutional capacity, strategic planning

Jel Codes: H11; H83; D73.

\title{
1. Giriş
}

Ulaştırma askeri, ekonomi ve insan hareketliliği bakımından her dönem önemli olmuştur. Bu bağlamda devletin ulaştırma sektöründe geniş bir rolü vardır. Bu rol doğrudan müdahale biçiminde olabileceği gibi, düzenleme, denetleme biçiminde de olabilir. Bir başka anlatımla, devlet ulaştırma politikasının geliştirilmesi, uygulanması, koordinasyonu ve değerlendirmesini gerçekleştirmektedir.

Ülkelerin gelişmişlik düzeyi, coğrafi konumu gibi bir dizi etken ulusal ulaştırma politikasının içeriğini belirlemektedir. Türkiye'de karayolu ağırlıklı ulaştırma politikası benimsenmiştir. Cumhuriyetin başında, Osmanlı devletinden devralınan yapının da etkisiyle, demiryolunun göreceli ağırlı̆̆ bulunmaktayken, 1940'li yılların sonundan başlayarak karayoluna doğru bir yönelim olmuştur ve bu 
yönelim hizlanarak günümüze kadar devam etmiştir (Güven, 1982: 38117; Tekeli, 2010: 1-48; Çakar ve Bayrakçı, 2016: 4-8).

Bu çalışmanın amacı; devletin karayolu ulaştırmasında üstlendiği rolü yerine getiren örgütün, görevlerini etkili ve verimli biçimde yerine getirip getirmediğini incelemektir. Bir başka deyişle, karayolu ulaştırma hizmetini yerine getiren örgütün, Karayolları Genel Müdürlüğünün, kurumsal kapasite bağlamında görevlerini yerine getirmedeki yeterliliğini değerlendirmektir.

Karayolları Genel Müdürlüğü (KGM)'nin görevlerini etkili ve verimli biçimde yerine getirmesi, Türkiye' de karayolu ulaştırmasının ulaştırma sistemi içindeki ağırlığı ve ulaştırmanın diğer sektörlerle çok yönlü etkileşimi nedeniyle önemlidir.

Çalışmada KGM'nin kurumsal kapasitesi ile ilgili verileri içeren 2006-2023 yıllarını kapsayan dört strateji planı karşılaştırmalı olarak incelenmektedir. Çalışma belge incelemesi tekniğini kullandığından etik kurul izni gerekmemektedir. Çalışmanın ilk kısmında literatür taraması yer almaktadır. Sonraki kısım kurumsal kapasite kavramı üzerinedir. Son kısım ise KGM'nin kurumsal kapasitesinin çözümlenmesine ayrılmıştır.

\section{Literatür Taramasi1:}

Çeşitli bilim dallarınca incelenen karayolu ulaştırmasına ilişkin başta mühendislik olmak üzere doğa bilimleri alanında çok sayıda lisansüstü çalışma bulunmaktadır. Karayolu ulaştırmasına ilişkin sosyal bilimler alanındaki çalışma sayısının sınırlı olduğu görülmektedir. Kamu yönetimi alanında hazırlanan tezler açısından bakıldığında ise yalnızca bir çalışma bulunmaktadır. Bu çalışma münhasıran personel politikası ile ilgili olan Yalçın Ataşlığlu'nun "Personel Çalıştırma Usulleri ve Karayolları Örneği (1990)" başlıklı tezidir. $^{2}$

Kamu yönetimi alanı dişında olmakla birlikte araştırma bağlamında belirtilmesi gereken lisansüstü çalışmalar şu şekilde

\footnotetext{
${ }^{1} \mathrm{Bu}$ kısımda incelenen tez, makale ve kitaplara metin içinde ayrıca atıf verilmedikçe kaynakçada gösterilmemiştir.

2 Bu tez incelemeye kapalıdır.
} 
sıralanabilir; Saroğlu'nun “Türkiye'de Karayolları Politika, Uygulama ve Çalışmalar" (2010) başlıklı yüksek lisans tezinde karayollarının tarihsel gelişimi ve uygulanan politikalar incelenmiştir. Betimleyici bir çalışma olup belge analizi tekniği kullanılmıştır. ${ }^{3}$ Karaali'nin "İdare Hukuku Açısından Karayolları Yapımı ve İşletilmesinde İdari Denetim Yetkisi" (2019) başlıklı yüksek lisans tezi, karayollarındaki yapım ve işletme faaliyetleri üzerindeki idari denetimi incelemektedir. Sakça'nın “Türkiye Karayollarında Yap-İşlet-Devret (YID) Modelinin İncelenmesi" (2013) başlıklı yüksek lisans tezinde karayolu ulaşım altyapı projelerinde YID modelinin uygulanabilirliği araştırılmıştır. Kaya'nın "Türkiye'de Karayollarının Gelişimi ve Karayolu Politikası" (1998) tezinde karayolu ulaşımındaki gelişmeler özetlenmiştir. Ceylan'ın "Karayolları Genel Müdürlüğü'nde Halkla İlişkiler Faaliyetleri" (1997) başlıklı yüksek lisans tezinde, halkla ilişkilerin önemi ve gereği bağlamında, Karayolları Genel Müdürlüğünün halkla ilişkiler faaliyetleri incelenmiştir.

Belirtilen tezler dişında karayollarını çevresel boyutu ile inceleyen tezler ile ulaştırma sektörünü (dolayısıyla karayollarını) münhasıran ya da Avrupa Birliği (AB) ile ilişkiler bağlamında inceleyen tezler de bulunmaktadır.

Yukarıda belirtilen tezlerde, Saroğlu'nun çalışması dışarıda birakılırsa, KGM'nin kurumsal kapasitesine yönelik doğrudan bir değerlendirme bulunmamaktadır.

Karayollarına ilişkin hazırlanan kitap ve makaleler incelendiğinde örgütün kurumsal kapasitesi bağlamında doğrudan bir araştırma bulunmamaktadır. Kitap ve makalelerin bir kısmı tarihsel inceleme yapmakta geri kalan kısmı iktisadi boyuta odaklanmaktadır.

KGM'nin kurumsal kapasite ile ilgili çalışmalar ayrıntılı olarak stratejik planlarda bulunmaktadır. 5018 Sayılı Kanun ile stratejik planlama çalışmaları başlatılmış; bu kapsamda kurumsal kapasite

\footnotetext{
3 İktisat anabilim dalında tez hazırlayan Saroğlu (2010:3-5) çalışmasında literatür taraması yapmıştır. Karayolu üzerine az sayıda çalışma olduğunu, var olan çalışmaların da belirli bir zaman kesitini kapsadığını tespit etmiştir. Saroğlu'nun taraması sonucu belirlediği kitap, makale ve tezlerin tamamı (dokuz adettir) iktisadi ağırlıklı olup, bu çalışma kapsamında değildir.
} 
analizleri stratejik planlarda ve onun uzantisı olan faaliyet raporlarında ve performans programlarında kendisine yer bulmuştur.

Literatür incelemesinin gösterdiği gibi, KGM'nin örgütlenme ve işleyişini araştırma odağına alan çalışma sayısı sınırlıdır. Ayrıca yapılan çalışmalar kamu yönetimi perspektifi ile yapılmamıştır, kurumsal kapasite boyutu yok ya da sinırlıdır. Bu nedenle karayolu ulaştırmasındaki temel aktörün kurumsal kapasitesini incelemek alan açısından önemli ve özgündür.

\section{Kurumsal Kapasite}

Kapasite kavramı farklı bilim alanlarında kullanılmaktadır. Kavrama ilişkin farklı perspektifler kapasite tanımlarında çeşitliliğe yol açmaktadır. Yetenek ve performans gibi kavramların kapasite ile eş anlamlı kullanılması da karmaşıklığa neden olmaktadır (Çolak, 2019: 5-6; UNDP, 2009: 5). Birleşmiş Milletler Kalkınma Programı (UNDP, 2009: 53) kapasiteyi: "Bireylerin, kurumların ve toplumların işlevleri yerine getirme becerisi, sorunları çözme ve sürdürülebilir bir şekilde hedefler belirleme ve gerçekleştirme" olarak, kurumsal kapasiteyi ise "örgütün görevlerini yerine getirmesini ve yetki kullanabilmesini, birlikte çalışmak ve hedeflere ulaşmak için bireysel kapasitelerin bir araya getirilmesini sağlayan iç politikalar, düzenlemeler, prosedürler" olarak tanımlamaktadır. ${ }^{4}$

Kamu İdarelerince Hazırlanacak Faaliyet Raporları Hakkında Yönetmelik'te (2006) kurumsal kabiliyet ve kapasitenin değerlendirilmesi başlıklı bentte "orta ve uzun vadeli hedeflere ulaşılabilmesi sürecinde teşkilat yapısı, organizasyon yeteneği, teknolojik kapasite gibi unsurlar açısından içsel bir durum değerlendirmesi yapılarak idarenin üstün ve zayıf yanları" nın ortaya konması (md. 18/ç) biçiminde açılamaktadır. Bu bağlamda

\footnotetext{
${ }^{4}$ Çolak'ın (2019: 38) literatürden derlediği üç kurumsal kapasite tanımı şu şekildedir; 1. "Bir örgütün koyduğu hedefleri minimum israf, eksik ve işlevsel bozukluk ile gerçekleştirmesi” (Honadle); 2. “Sorunları tanımlama, sorunlara yönelik çözüm odaklı politikalar üretme, bunları geliştirme, değerlendirme ve hükümet operasyonlarını yönetme" (Howitt); 3. "kamu yönetiminin problem çözme becerisi" (Lodge ve Weigrich).
} 
yönetmelik kurumsal kapasitenin unsurlarını; "teşkilat yapısı, organizasyon yeteneği, teknolojik kapasite" olarak saymıştır.

Kutlu (2012: 11; 2013: 460-464) kurumsal kapasitenin beş bileşeni olduğunu belirtmektedir. Bunlar; kurumsal kaynaklar, yönetim yaklaşımı, kurum kültürü, kurumsal ilişkiler ve mevzuat analizidir. Kurumsal kaynaklar, başta insan olmak üzere teknik, fiziksel ve mali kaynaklardır. Yönetim yaklaşımı iş yapma biçimidir. Bu başlık altında katılımcı bir yönetim var mı, eleştiri ve değerlendirmeler dikkate alınıyor mu sorularının yanıtları önemlidir. Kurum kültürü, kurumun deneyim ve gelenekleri ile sembollerini kapsamaktadır. "Kurum kültürü, kurumsal kaynak ve tecrübelerin etkileşimi neticesinde oluşan, kurum performansını etkileyen değer, yaklaşım, gelenek ve kalıplardır". İlişkiler kurum içi ve kurum dışı ilişkileri içermektedir ve kurum içinde işbirliği ortamını, kurum dışında ise dış paydaşların süreçlere dahil edilmesini anlatmaktadır. Son bileşen olan mevzuat kurumun başarısını doğrudan etkileyen bir unsurdur. Kurumların önlerini açıp, işlerini kolaylaştırabileceği gibi tersine bir etki de yapabilir.

Avrupa Komisyonu düzenlediği bir eğitimde kurumsal kapasitenin temel unsurlarını şu şekilde belirtilmektedir (Van Bork, 2014): 1. Yapılar: Görev, yetki ve sorumlulukların net biçimde belirlenmesi. 2. İnsan kaynakları: Personelin işe alımından başlayarak, eğitimi, terfisi ve diğer personel işlemleri 3. Sistem ve araçlar: Yönergeler, risk yönetimi araçları, kalite güvence araçları, bilgi teknolojileri araçları vb. Anılan eğitimde bu üç unsurun yanı sıra yönetişimin (hesap verebilirlik, süreçlere paydaş katılımı vb.) gerekliliği üzerinde durulmaktadır.

Matachi (2006: 5) kurumsal kapasite ile bağlantılı unsurları: insan kaynakları, fiziksel kaynaklar, entelektüel kaynaklar (örgütsel strateji, stratejik planlama, süreç yönetimi gibi), kurum içi bağlantılar (ağlar, ortaklıklar), inisiyatif ve ödül sistemi, örgüt kültürü ve yöneticilerin liderlik özellikleri olarak sıralamaktadır. Kocaoğlu (2019) kurumsal kapasite ile ilgili derleme makalesinde, literatürde farklı 
adlandırmalar ${ }^{5}$ olsa da, kurumsal kapasiteye ilişkin benzer unsurların kullanıldığını tespit etmiştir.

Görüldüğü üzere kurumsal kapasitenin varlığı yalnızca para ve nitelikli personel gibi kaynaklarla ilgili değildir. Hedeflerin net olarak belirlenmesi, hedeflere ulaşacak araçlara, güce ve isteğe sahip olmak, yeterli yetki ve bağımsız karar alabilme gibi unsurlar da önemlidir (Kurşunlu, 2004: 37).

Kurumsal kapasiteye ilişkin darboğazlardan birkaçı şu biçimde belirtilebilir (Van Bork, 2014: 6-8): 1. Proje seçiminde ve personel atamalarında uygun olmayan/aşırı siyasi müdahale, 2. Yeterli nitelik ve deneyimde personel yokluğu ya da yüksek işgücü devir hızı, 3.Gelişmeyi izleyen sistemlerin ve veri kalitesinin yetersizliği, 4 . Bağımsız değerlendirmelerdeki önerilerin uygulamaya yeterince aktarılmaması ya da değerlendirmelerin kalitesindeki sorunlar, 5. Mevzuata uyulmaması ya da mevzuat yokluğu.

Kurumsal kapasiteyi yatay ve dikey (Pollitt ve Bouckaert, 2002: 41; Verheijen, 2000: 7-8) olarak ikiye ayıran AB, yatay kurumsal kapasiteyi: "tarafsız ve profesyonel bir kamu yönetimi; kamu personeli eğitim sisteminin geliştirilmesi; yeterli politika oluşturma ve eşgüdüm kapasitesi; etkili bir hesap verebilirlik sistemi (iç ve dış mali kontrol sistemine özel bir önem atfedilmesi); $A B$ ile ilgili işlerinin yönetimi için oluşturulan özel yapı ve prosedürlerin boyutu; kamu yönetimi reform stratejisi olup olma"ması üzerinden değerlendirmektedir (Kurşunlu, 2004: 26; Verheijen, 2000: 7-8).

Ekonomik İşbirliği ve Kalkınma Örgütü (OECD), Birleşmiş Milletler gibi uluslararası örgütler de kurumsal kapasite üzerinde durmaktadır. Örneğin OECD'nin 2011 yılı Türkiye Değerlendirme Raporu'nda (OECD, 2011: 5) kamu idaresinin kapasitesine ilişkin genel değerlendirmeler ve kurumsal kapasitenin geliştirilmesine yönelik öneriler bulunmaktadır. 6

\footnotetext{
${ }^{5}$ Farklı adlandırmalar konusunda bkz. (Addison, 2009). Bu çalışmada kurumsal kapasite ile idari kapasite eş anlamlı olarak kullanılmaktadır.

${ }^{6}$ Devlet Memurları Kanununun kimi yönlerden güncelliğini yitirdiği, maaş düzeninin aşırı karmaşık ve ayrımcı olduğu, istihdam ve eğitim sisteminde sorunlar bulunduğu ve kamu yönetimde standartların olmadığı belirtilmektedir (OECD, 2011: 5). Öneriler
} 
Kapasitenin geliştirilmesi kamu yönetiminin başlica konularındandır (Kutlu, 2012: 4). Birleşmiş Milletler Kalkınma Programı (UNDP, 2009: 19), kapasite geliştirme için üç temel soru yöneltmektedir;

1. Kapasite geliştirmeye gerek var mı? Amaç nedir?

2. Kimlerin (hangi grubun) kapasitesi geliştirilecek?

3. Ne türden kapasiteler geliştirilmeli?

UNDP, kurumsal kapasitedeki gelişmeyi ölçmek için üç temel unsuru etkililik ve verimlik artı̧̧ı (performans artışı), istikrar (kurumsallaşma) ve adaptasyon (büyüme, değişim ve sürekli gelişim) olarak saymaktadır (UNDP, 2009: 48).

Kurumsal kapasite analizi, kurumun görevlerini yerine getirirken yeterli kaynağı olup olmadığını ve sunduğu hizmetleri başarılı bir düzeyde yerine getirip getirmediğini incelemek olarak tanımlanmaktadır (Kutlu, 2012: 70).

Kökenleri 1950'li yıllara uzansa da 1980'li yılların ortalarında dünyada yeniden popülerleşmeye başlayan (Addison, 2009: 1) kurumsal kapasite kavramının Türkiye'de gündeme gelmesinde AB'ye üyelik süreci önemli bir etkendir.7 AB İlerleme Raporları, Ulusal Programlar kurumsal kapasiteye ilişkin düzenlemeler, açıklamalar, yorumlar içermektedir. Örneğin 2001 yılı Ulusal Programında mali kontrol bağlamında yapılan tespite göre: “Türkiye'nin Topluluk özkaynaklarına katkı düzeyini düzgün bir şekilde hesaplayacak idari kapasitesinin yanında, Topluluk bütçesine tahsis edilen kaynakları layıkıyla toplayacak ve zamaninda transfer edecek idari kapasiteye de sahip olması zorunludur" (Ulusal Program, 2001: 430).

için bkz. (OECD, 2011: 7). Kapasite geliştirme yaklaşımının popülerleşmesinde Dünya Bankası ve Birleşmiş Milletler Kalkınma Programının etkisi için bkz. (Çolak, 2019: 29; Addison, 2009: 4). AB'nin konuya yaklaşımı için bkz. (Kutlu, 2012: 4).

7 Kavramın Avrupa'da popülerleşmesinde AB genişleme süreci etkilidir (Addison, 2009:4). Kurşunlu (2004: 25,33) AB müktesebatının uygulanması için gerekli kurumsal kapasitenin bir üyelik koşulu olmasının 1993 Kopenhag Zirvesi'nde “AB müktesebatını üstlenebilme yeteneği" bağlamında gündeme geldiğini ancak ilk kez 1995 yılında Madrid Zirvesi Sonuç Bildirgesinde üstü kapalı biçimde dile getirildiğini belirtmektedir. 
2003 yılı Ulusal Programı'nda kurumsal kapasite konusu detaylandırılmıştır. "Müktesebatın uygulanmasına yönelik idari kapasite" ve bunun geliştirilmesinin araçları (eşleştirme/twinning, ikili mali işbirlikleri, idari işbirlikleri, teknik destek-bilgi değişim vb.) belirtilmiştir (Ulusal Program, 2003: 774-783).

Türkiye'de, kurumsal kapasite bağlamında, AB süreci dışında 5018 Sayılı Kanun ve bu kanun kapsamında yapılan düzenlemeler önem taşımaktadır. Kanunda ve Kamu İdarelerinde Stratejik Planlamaya İlişkin Usul ve Esaslar Hakkında Yönetmelikte kurumsal kapasiteye doğrudan atıfta bulunulmamakla birlikte; "stratejik plan" tanımlanmaktadır. Kamu İdareleri İçin Stratejik Planlama Kılavuzu'nda ise kurumsal kapasiteye yer verilmiştir (Kalkınma Bakanlığı, 2018a: 39).

Kılavuzda kurumsal kapasitenin dört unsuru olarak; insan kaynağı, fiziki kaynaklar, teknolojik kaynaklar ve mali kaynaklar olarak belirtilmektedir (Kalkınma Bakanlığı, 2018a: 82).

Türkiye'de görece yeni kullanılmaya başlayan kurumsal kapasite kavramı temel politika belgelerinde, özellikle stratejik planlarda geçmektedir. Aşağıdaki kısımda karayolu ulaştırma hizmetinde temel aktör olan KGM'nin kurumsal kapasitesi stratejik planlar üzerinden incelenmektedir.

\section{Karayolu Ulaştırma Hizmetlerinin Yerine Getirilmesindeki Temel Aktör Olan KGM ve Kurumsal Kapasitesi}

Karayolları ulaştırması bağlamında temel aktörlerden ilki Bakanlık, ikincisi KGM'dir. Çalışmanın kapsamı nedeniyle Bakanlıkla ilgili değerlendirme yapılmamaktadır. Ulaştırma sektöründe sorun alanlarından birisinin de kurumsal kapasite eksikliği olduğu çeşitli çalışmalarda (Çakar ve Bayrakçı, 2016: 68; Kalkınma Bakanlığı, 2018b: xv) belirtilmektedir. 11. Kalkınma Planı Ulaştırma Özel İhtisas Komisyonu Raporunda KGM, kurumsal yapısı güçlendirilmesi gereken bir kurum olarak anılmaktadır. ${ }^{8} 2018$ yılı Sayıştay Denetim

\footnotetext{
8 Rapor'da "karayolu taşımacılık piyasasını yöneten kamu otoritesinin kurumsal yapısının güçlendirilmesi" (Kalkınma Bakanlığı, 2018b: xv) biçiminde bir ifade bulunmaktadır.
} 
Raporu incelendiğinde KGM'ye ilişkin tespit edilen otuz üç bulgudan çoğunun ve Rapor'daki diğer açıklamaların doğrudan ya da dolaylı olarak örgütün kurumsal kapasitesindeki eksikliklere işaret ettiği görülmektedir (Sayıştay, 2019). ${ }^{9}$

\section{1. KGM Hakkında Genel Bilgiler}

KGM otoyol, devlet yolu ve il yollarınin yapım, bakım ve onarım sürecinden sorumludur. Ulaştırma ve Altyapı Bakanlığı'nın bağlı kuruluşudur, tüzel kişiliği bulunmaktadır. Hizmetlerinin yararlanıcıları salt vatandaşlar değildir, hizmetlerinin uluslararası boyutları bulunmaktadır. $\mathrm{Bu}$ anlamda uluslararası ve bölgesel işbirlikleri yapmaktadır (KGM tarihsiz b: 26, 48).

KGM'nin 2019 tarihi itibarıyla personel sayıs 24.329'dur. Personelinin yaklaşık \%25'i memur, \% 74'ü işçi' dir (KGM tarihsiz b: 32-33). Son yıllarda sözleşmeli personel sayısında, kamu personel rejimindeki genel eğilimi uygun olarak, bir artış görülmektedir. 2020 yılı için $K^{\prime} M^{\prime}$ ye verilen açıktan ve naklen atama memur sayısı $5^{\prime}$ tir (KGM, 2020: 26).

Tablo. 1: KGM Personel Sayısının Yıllar İçindeki Gelişimi

\begin{tabular}{|l|c|c|c|c|}
\hline Y1l & İşçi & Memur & Sözleşmeli Pers. & Toplam \\
\hline 1977 & 47.339 & 3.162 & - & 50.501 \\
\hline 2006 & 15.226 & 5.140 & 1 & 20.367 \\
\hline 2019 & 20.702 & 6.124 & 1051 & 24.329 \\
\hline
\end{tabular}

Kaynak: (KGM, 2007: 13; KGM tarihsiz b: 31)

KGM 1980'li yıllara kadar emanet usulü ile yapım çalışması gerçekleştirirken (hizmetler doğrudan kurumun kendi personeli ile gerçekleştirilirken), özellikle 1980'li yıllardan itibaren yapım ve bakımın ihale usulü ile yapılmasına yönelinmesi sonucunda, personel

\footnotetext{
9 Bulgulara örnek olarak "Yap İşlet Devret Projeleri müşavirlik ihalelerinde mevzuata aykırılıkların bulunması", "projelerinin doğru hazırlanmaması sonucu imalatlar ve projeler için birden fazla ödeme yapılması" verilebilir. (Sayıştay, 2019: 161, 165, 170172).
} 
sayısında azalma olmuştur. ${ }^{10}$ Personel sayısındaki azalmanın ikinci nedeni ise teknolojik gelişmelerdir (KGM, 2007: 13). ${ }^{11}$

Kapatılan veya özelleştirilen kamu kurumlarından devredilen personel ile hizmet alım işlerinde çalışan taşeron personelin kadroya alınması sonucu, diğer yıllara göre 2015 yılında personel sayısında göreli bir artış olmuştur (KGM, 2016: 19, 55, 57).

2014 ve 2015 y1llarında "Asfalt Yol Bakım" ve "Kar Mücadelesi" işlerinin ağırlıklı olarak ihaleli yapılmasından dolayı söz konusu işlerde çalışan işçiler bölgelerdeki şube merkezlerine kaydırılmıştır (KGM, 2016: 57); bu durum atıl kapasite yaratmıştır.

İhaleli ve emanet bakım hizmetlerinin yüzdesel pay dağılımları incelendiğinde; 2005-2010 yılları arasında bakım hizmetlerine ayrılan emanet harcamaların payı yüksekken (ortalama \%75 emanet, \%25 ihaleli), 2010 yılından itibaren özel sektör eliyle gerçekleştirilen bakım hizmetlerinde artış görülmüştür. Son yıllarda bu dağılım yaklaşık yarı yarıyadır (KGM, 2016: 57).

KGM faaliyet raporlarında 2011 yılından başlayarak temel değerlerinden birisi olarak "kariyer planlamasına önem verilmesi" belirtilmektedir. Bununla birlikte kariyer planlamasına yönelik özel bir çalışmadan faaliyet raporlarında söz edilmemektedir (KGM tarihsiz b: 14; KGM tarihsiz c: 14; KGM tarihsiz d: 14). Kurumsal kapasite incelenirken kariyer planlaması konusuna yeniden değinilecektir.

\subsection{Stratejik Planlarda KGM'nin Kurumsal Kapasitesi}

Aşağıdaki kısımda Stratejik Planlarda KGM'nin kurumsal kapasite açısından nasıl değerlendirdiği incelenmektedir. Bir yandan günümüzdeki durumu görmek, diğer yandan yakın geçmişten günümüze gelişimi görebilmek bakımından inceleme kurumun ilk stratejik planını yaptığı 2007-2011 Planından başlatılmaktadır.

\footnotetext{
10 Beyaz yakalı personel sayısındaki göreli artışa rağmen personel sayısı azalmıştır (bkz. Tablo 2.)

112010 yılında KGM' de örgütlü sendika, personel açığı olduğunu ve bu açığın kadrolu personelle giderilmesi gerektiğini belirtmektedir (Yapı-Yol Sen, 2010). Yetkili sendika olan Bayındır Memur-Sen'in KGM yetkilileri ile 2015 ve 2017 yılında yaptığı kurum idare kurulu toplantı kararları incelenmiş olup, kurumsal kapasite bağlamında önemli bir bilgiye rastlanmamıştır (KGM, 2015; 2017).
} 
Stratejik planlamanın ${ }^{12}$ varlık nedeni kaynakların amaç ve hedefler doğrultusunda kullanılabilmesine, fırsat ve tehditlerin zamanında belirlenerek etkili bir yönetimin oluşturulmasına katkıda bulunmaktır (KGM, tarihsiz e: 9). Bu bağlamda stratejik planlar kurumsal kapasitenin belirlenmesi, değerlendirilmesi ve geliştirilmesi açısından önem taşımaktadır. Nitekim, Kamu İdareleri İçin Stratejik Planlama Kılavuzu'nda stratejik planlamanın amaçlarından birisinin de kurumsal kapasitenin geliştirilmesi olduğu belirtilmektedir (Kalkınma Bakanlığı, 2018a: 39).

KGM'nin 2017-2021 Stratejik Planı iki yıl içinde uygulamadan kaldırılmıştır. 2017-2021 ile 2019-2023 Planları karşılaştırıldığında büyük ölçüde benzerlikler içermektedir. Bir başka anlatımla, 2019-2023 Planı, 2017-2021 Planı'nın gözden geçirilerek yenilenmiş biçimidir.

Aşağıda öncelikle KGM'nin stratejik planları hakkında kısa açılamalar yapılmakta, daha sonra planlar kurumsal kapasite bağlamında incelenmektedir. İnceleme kurumsal kapasitenin bileşenlerine göre ${ }^{13}$ (kurumsal kaynaklar, kurum kültürü, yönetim yaklaşımı-kurumsal ilişkilere) yapılmaktadır. Kuşkusuz bileşenlerin içerikleri arasında geçişler olabilmektedir. $\mathrm{Bu}$ nedenle başlıklandırmaya gidilmeden, değerlendirmeler ortak bir başlık altında yapılmıştır.

\subsubsection{7-2011 Stratejik Planı}

Plan döneminde KGM Bayındırlık Bakanlığ $1^{14}$ bünyesindedir. 2006 yılında genel bütçeli kuruluşlar arasına dahil edilerek tüzel kişiliği kaldırılmıştır. ${ }^{15} 2000$ 'li yılların başında stratejik planlama konusu Türkiye' de yenidir ve stratejik plan yapmak üzere pilot kurumlardan birisi olarak KGM seçilmiştir.

12 İlgili kanuna göre stratejik planlama; "kamu idarelerinin orta ve uzun vadeli amaçlarını, temel ilke ve politikalarını, hedef ve önceliklerini, performans ölçütlerini, bunlara ulaşmak için izlenecek yöntemler ile kaynak dağılımlarını içeren plan"dır. (5018 SK, md. 3/n)

${ }_{13}$ Mevzuat veri kabul edilerek değerlendirme dışı bırakılmıştır. Yönetim yaklaşımı ile kurumsal ilişkiler aynı başlık altında incelenmektedir.

142007 yılında Ulaştırma Bakanlığı bünyesine alınmıştır (KGM, 2008).

15 KGM 2006 yılında genel bütçeli kuruluşlar arasına dahil edilerek tüzel kişiliği kaldırılmıştır. 2010 yılında yeniden tüzel kişilik kazandırılmıştır (KGM tarihsiz, f: 28). 
Planda, stratejik planlama çalışmalarının KGM'nin sorunlarını/darboğazlarını ortaya çıkarmak, bu sorunların aşılarak kurumun daha verimli bir yapıya kavuşturulması yönünde politika ve stratejiler belirlemek amacıyla başlatıldığı belirtilmektedir (KGM, tarihsiz g).

Planda "kurumsal kapasite" başlığına yer verilmemiştir. Buna karş1lı üçüncü amaç "Kurumsal Mükemmeliyet Ve Sürekli Gelişme" olarak belirlenmiştir. Amacın altbaşlı̆g 1 "Eğitim, AR-GE ve teknolojiye önem veren sürekli gelişmeye açık kurumsal yapı oluşturmak, kurum çalışanlarının gelişimini ve iş tatminini sağlamak"tır. Amaçla ilgili unsurlar incelendiğinde, kurumsal kapasiteye benzer bir kavramsal çerçevenin oluşturulduğu görülmektedir.

Bu amaca yönelik beş hedef belirlenmiştir. Hedefler şunlardır; 1.5 yıl içerisinde akıllı ulaşım sistemleri uygulaması yaygınlaştırılacaktır, 2. Kurum içi ve kurum dışı eğitime ağırlık verilecektir, 3 . Kurum çalışanlarının kurumsal memnuniyeti 5 yıl içerisinde \%10 artırılacaktır, 4. Karar destek ve yönetim sistemleri geliştirilerek 5 yıl içerisinde kullanıcıların hizmetine sunulacaktır, 5. Kurumun kalite kontrol deney laboratuvarları 5 yıl içerisinde geliştirilecektir.

$\mathrm{Bu}$ genel açıklamalar ışı̆̆ında kurumsal kapasite bileşenlerine göre incelendiğinde şu tespitler yapılabilir;

Planda mali kaynakların yetersizliği, proje yüküyle uyumlu olmayan yetersiz ödenek miktarları vurgulanmaktadır (KGM, tarihsiz g: 27, 29-30); "karayolu projelerinin ekonomiye bir an önce kazandırılması amacıyla bütçe ödeneklerinin en az \%50 arttırılması gerekmektedir" (KGM, tarihsiz g: 27). “Otoyol yapım ve işletme faaliyetleri genel bütçeden ayrılan kısıtlı kaynaklarla sürdürülmektedir." (KGM, tarihsiz g: 29). "KGM'nin üzerinde ulaştırma açısından bu kadar yük var iken ayrılan ödenekler açısından benzer oranlar gerçekleşmemektedir" (KGM, tarihsiz g: 29).

İnsan kaynakları yönüyle bakıldığında da yetersizlikler belirtilmektedir; "...mevcut teknik personel sayıs ihtiyac1 karşılayamamaktadır" (KGM, tarihsiz g: 31). "İhaleli yapıma geçiş ve teknolojik gelişmeler personel sayısını azalmıştır" (KGM, tarihsiz g: 35). KGM'nin sorumluluklarını gerçekleştirebilmesi için nitelikli 
teknik personele ihtiyaç duyulduğu belirtilmektedir; "...kurumlararası farklı ücret politikaları nedeniyle nitelikli personelin sürekli istihdamında güçlük çekmektedir" (KGM, tarihsiz g: 35). Ücret politikalarındaki olumsuzluklar nedeniyle, deneyimli personel oranının giderek azaldığı, ücret dengesizliklerinin çalışma barışını olumsuz etkilediği, motivasyonu düşürdüğü belirtilmektedir.

Kurum çalışanlarına uygulanan ankette16 "Aldığım Ücret Tatmin Edicidir" maddesine yanıt verenlerin \%88'i bu yanıta katılmadığını ifade etmiştir. Anket sonuçlarından kurum içerisinde takdir ve kendini gerçekleştirme konularında da problemler olduğu anlaşılmaktadır (KGM, tarihsiz g: 52).

KGM'nin mali ve insan kaynağı dışındaki en önemli kaynağ1 Makine Parkı'dır. Makine Parkı açısından da yetersizlik bulunduğu belirtilmektedir; "Kuruluşun çalışma politikası doğrultusunda, son 15 yılda yol yapım çalışmaları ihaleli olarak yapıldığı için yenilenmesi gereken yapım makineleri yenilenmemiştir." "Makine parkının mevcut hali ile yol bakım ve kış mücadelesi hizmetleri güçlükle yerine getirilmekte, hizmetin yürütülmesinde aksamalar olmaktadır" (KGM, tarihsiz g: 35-36).

Kurumun Güçlü-Zayıf-Fırsat-Tehdit (GZFT) analizinde kaynaklar konusundaki eksiklikler, özellikle insan kaynakları bağlamında vurgulanmaktadır (KGM, tarihsiz g: 53); "Memur statüsünde çalışan personelin ücretlerinin yetersizliği; atama ve terfilerde zaman zaman liyakat ve kariyerin dikkate alınmaması; Sanat sınıfı personelin yaşlı oluşu; memur personel ile ücret dengesizliği; teşkilat içi personel planlamasının yapılamaması; personel motivasyonu için yeterli gayret gösterilmemesi; bakım ve işletmeye dönük makine ve personel yapısının yetersiz" olduğu belirtilmektedir ${ }^{17}$.

Kurumun GZFT analizinde zayıf olunan alanlarından birisi olarak “...politikacıların yatırım programı dışındaki taleplerinde etkin

16 Planda ankete katılım oranı belirtilmemiştir. Bu durum bilimsel açıdan önemli bir eksikliktir.

17 Bu sorunlar aynı zamanda "AR-GE çalışmalarının yetersizliği" ile "taşıt muayene istasyonlarında yeterli hizmet verilmeyişi" sorunlarının da kaynağını oluşturmaktadır. 
olması" belirtilmektedir. Rasyonel planlama açısından sakıncalı olan bu durum iş yapma usulleri ile kurum dışı ilişkiler bakımından sorunlara da işaret etmektedir. İlişkiler bağlamında "kuruluşun halkın projelere katılımına ve görüşlerine yeterince önem vermeyişi" tespiti de kurumun bir eksikliği olarak görülmektedir.

GZFT analizinin tehditler kısminda "siyasilerin olumsuz müdahaleleri sonucu" kurumun zayıfladığı belirtilmiştir.

Planda çalışanların, kurumda çalışmaktan mutlu oldukları ve gurur duydukları, kurum çalışanları arasında iyi bir iletişim olduğu, KGM çalışanları arasında kullanılan "Karayolculuk Ruhu" kavramının gelecek nesil çalışanlarına da aktarılması gereken bir değer olduğu belirtilmektedir (KGM, tarihsiz g: 51-52). Bununla birlikte ilgili anket ${ }^{18}$ sonucu incelediğinde, kurumu bir aile gibi görme sorusuna verilen yanitların "tamamen katıliyorum" ve "katıliyorum" toplaminin \%37 olduğu, "kısmen katıliyorum" yanıtının \%35 olduğu, dolayısıyla Plandaki yorumu destekleyen yanıt oranın \%72 olduğu görülmektedir (KGM, tarihsiz g: 77). Bir başka deyişle, bu konuda da kısmen problem bulunmaktadır.

Toplumda iyi anılan bir kuruluş olup saygınlığı vardır. Bu nedenle olsa gerek ki KGM çalışanları kuruluşta çalışmaktan mutludur. Ancak kuruluşun faaliyetlerinden bazıları arzu edilen notları alamamıştır. Ancak söz konusu faaliyetlerde kuruluşun zayıflı̆̆ı kuruluş çalışanları tarafından da bilinmektedir. Bu faaliyetlerdeki başarısızlığın büyük bir kısmı personel yetersizliği, ödenek yetersizliği ve kuruluşun yeterli inisiyatife sahip olamamasıdır (KGM, tarihsiz g: 52).

Kurumsal kapasite bileşenlerinin birbirleri ile karşılıklı etkileşimini göstermesi bakımından Plandaki bu tespit önemlidir. Mali ve insan kaynaklarının nitelik düzeyinin kurum kültürünü olumlu yönde besleyen bir unsur olduğu görülmektedir.

Sosyal faaliyet ve tesis eksikliği kurumsal kapasitenin hemen tüm bileşenlerini değişik ölçülerde etkileyebilecek bir unsurdur. Bu nedenle sosyal faaliyet ve tesis eksikliği konusunda var olan talepler

18 Ankete katılım oranının belirtilmemesi bir sorundur. 
(KGM, tarihsiz g: 53) önem taşımaktadır ve kurumsal kapasiteyi olumsuz etkilemektedir.

\subsubsection{2-2016 Stratejik Planı}

$\mathrm{Bu}$ plan döneminde KGM Ulaştırma Denizcilik ve Haberleşme Bakanlığının tüzel kişiliğe sahip bağlı kurumudur. 2012-2016 Stratejik Plan ile daha güçlü kurumsal bir yapıya kavuşmak konusunda iyimser olunduğu belirtilmektedir (KGM, tarihsiz f: 89).

2012-2016 Stratejik Planında amaçlardan üçüncüsü olan "Kurumsal Mükemmeliyet ve Sürekli Gelişme" amacı, alt başlığı da dahil olmak üzere önceki Planla aynıdır. Bu nedenle "Kurumsal Mükemmeliyet ve Sürekli Gelişme" amacı doğrultusunda belirlenen hedefler ve yapılacaklar da önceki Plan ile aynıdır.

Önceki planda yer almayan "kariyer planlamasına önem verilmesi"19 kavramı, aynı içeriğe sahip olmasa da, önceki planda var olan "atamalarda deneyim ve liyakati ölçü alma" ilkesi (KGM, tarihsiz g: 18) yerine kullanılmıştır. ${ }^{20}$

Kurumsal kapasite bileşenlerine göre incelendiğinde şu tespitler yapılabilir;

Mali kaynaklar konusunda sorunlar devam etmektedir. "Yatırım programında karayolu yatırımlarına ayrılan payların genel bütçeden tahsis edilen ödeneklerle yürütüldüğü senelerdeki seviyesini koruması durumunda, ortalama proje tamamlanma süresi 10 yılı aşmaktadır, uzamanın ekonomik kayıplara yol açacağı açıtır" (KGM, tarihsiz f: 37).

Makine parkının \%52,5'i 16 yaş grubunun üzerinde (KGM, tarihsiz f: 40) olması önemli bir sorundur. "Kuruluşun çalışma politikası doğrultusunda, son 20 yılda yol yapım çalışmaları ihaleli olarak yapıldığı için yenilenmesi gereken yapım makineleri yenilenmemiştir"

19 Kariyer planlaması "personelin uzmanlık dalının geliştirilmesi desteklenerek çalışma koşullarını ve sosyal yaşam standartlarını iyileştirmek, kurum içi iletişimi açık tutmak" (KGM, tarihsiz f: 61) olarak açıklanmaktadır.

20 2012-2016 Planında amaçlara yönelik yer alan performans göstergelerinin bir kısmının ölçülebilir olmadığı, 2017-2021 Stratejik Planında belirtilmektedir (KGM, tarihsiz e: 18). 
(KGM, tarihsiz f: 40). "Makine parkının mevcut hali ile yol bakım ve kış mücadelesi hizmetleri güçlükle yerine getirilmekte, hizmetin yürütülmesi, devamlılığın ve beklenen kalite düzeyinin sağlanmasında aksamalar olmaktadır" (KGM, tarihsiz f: 40).

GZFT analizinde "aşırı proje yükü nedeniyle yetersiz kalan ödenekler" kurumun zayıf yanı olarak belirtilmektedir. Bakım çalışmalarına yeterli ödenek ayrılmadığı belirtilmektedir. Görüldüğü üzere mali kaynak alanında önceki Plan'daki tespit ve zayıflıklar sürmektedir.

İnsan kaynakları alanında da benzer bir durum bulunmakta ve önceki planda belirtilen sorunlar sürmektedir. Ek olarak özelleştirmeler sonucu KGM'ye atanan personele ilişkin yeni sorunlardan söz edilmektedir. Özelleştirmeler nedeniyle KGM'ye zorunlu olarak naklen atanan personel ile diğer kurum ve kuruluşlardan naklen atanan personelin tüm personel içerisinde sayılarının arttığı, bu durumdaki personelin kariyerine ve işin özelliğine göre en yüksek verim alınabilecek alana yerleştirilmeleri konusunda zorluklar yaşandığı, ayrıca bu personelin kurum kültürüne intibaklarının da uzun bir süreç alacağı belirtilmektedir (KGM, tarihsiz f: 33).

Kurum içi ve kurumlar arasındaki ücret dağılımı adaletinin olmaması, kurum içi kariyer planlaması yapılamaması konuları çalışanların memnuniyetsiz olduğu diğer hususlardır. Sosyal faaliyetlerin ve tesislerin de yetersiz olduğu tespiti önceki planda olduğu gibi sürmektedir. Sosyal faaliyet ve tesis eksikliği, mali kaynak yetersizliğini gösterdiği gibi, kurumsal aidiyetin oluşmasını sağlayacağ ilişkilere yönelik olumlu bir hava yaratılmasını da olumsuz etkileyebilmektedir. Nitekim KGM çalışanlarının bağlılığ 100 üzerinden 58,44 olarak belirlenmiştir. KGM çalışanlarının genel memnuniyet ortalaması 100 üzerinden 52,75 olarak hesaplanmıştır (KGM, tarihsiz f: 23-24) ki, her iki oran sinurdadır.

Kişisel ve mesleki gelişim için ihtiyaç duyulan eğitimlerin eksikliği ayrıca belirtilmektedir. Kurumun verdiği hizmetlere uygun, mesleğe özel yarışma sınavı ile alınacak kariyer uzmanlarının (karayolu 
uzmanı) istihdam edilememesi zayıflık olarak belirtilmektedir. ${ }^{21}$ Karayolu sektöründe çalışanların niteliklerinin teknolojik bilgi açısından en üst düzeye ulaştırılabilmesi için daha fazla kaynak ayrılarak kurum içi ve dışı eğitime ağırlık verilmesi (KGM, tarihsiz f: 68) gereği vurgulanmaktadır.

Planda öncekinden farklı olarak kurum kültürü başlıklı bir kısım bulunmaktadır. Bu başlık altında bir önceki planda gündeme getirilmiş olan "karayolculuk ruhu" sav sözü süregelmektedir. "Karayolculuk ruhu" temel değerlerden birisi olarak benimsenmiştir. Kavram "kurum kültürüne sahip çıkmak, etik değerlere bağlı olmak" (KGM, tarihsiz f: 61) biçiminde açıklanmaktadır.

Plan kapsamında kurum çalışanlarının geniş ölçüde katıldı̆̆ı (\%72) anket sonuçlarına göre; katılanların \%44'ü KGM'yi bir "aile", kendini de bu ailenin bir ferdi olarak görmektedir. Önceki planda yapılan ankette "aile" kavramı "ankete katılanların büyük kısmınca benimsenmiş" olarak belirtilmekle birlikte, ankete katılım ve benimsenme oranının belirtilmemesi nedenleriyle, ayrıca 2012-2016 Planında oranların verilmesi ve görece yüksek katılım nedeniyle, yeni plandaki verileri daha gerçekçi olarak değerlendirmek uygun görünmektedir. $\mathrm{Bu}$ sonuca göre kurumsal aidiyet yeterince sağlanamamıştır.

GZFT analizinde "personelin kurumsal sorumluluklarına dair karşılaştıkları hukuksal sıkıntılarda, kurumdan yeterli destek bulamaması" tespiti, kurum kültürünü zedeleyici bir durumdur. Aynı biçimde, GZFT'de "hizmet yılı az olan teknik hizmetler sınıfı personelinin kuruma bağlılığının oluşturulamaması" belirlemesi, hem kurum kültürü hem de yönetim yaklaşımı-kurumsal ilişkiler bağlaminda önemlidir.

İki Plan arasında beş yıl bulunmasına rağmen "siyasilerin olumsuz müdahaleleri sonucu" kurumun zayıflaması tespitinin sürdüğü görülmektedir.

21 2012-2016 Planı'nda yeni bir hedef olarak “kurumda uzman ve uzman yardımcisı istihdam edilecektir" hususu belirtilmektedir (KGM, tarihsiz f: 70). 
GZFT'de "halkla ilişkiler" zayıf yan olarak belirtilmektedir. Bazı faaliyetlerde tanitım yetersizliği vurgulanmaktadır. Kurumun "halkın projelere katılımina ve görüşlerine yeterince önem verme"diğ belirtilmektedir. Bu durum kurum dışı ilişkilerdeki zayıflık olarak değerlendirilmelidir.

2012-2016 Planında "kurum çalışanlarının kurumsal memnuniyeti 5 yıl içerisinde \%10 artırılacaktır" hedefi korunmakta ancak 2007-2011 Planının değerlendirildiği kısımda belirlenen bu hedefe ulaşma ya da gerçekleşme derecesine ilişkin bir açılama bulunmamaktadır (KGM, tarihsiz f: 85). Açıklamanın olmamasını, herhangi bir ilerleme olmadığı biçiminde yorumlanmak gereklidir. Bu tespiti destekleyen bir unsur şudur; 2007-2011 Plan döneminde bu hedefin gerçekleştirilmesine yönelik olarak belirlenen faaliyet "her yıl sosyal tesis ve idari binaların bakım ve onarımı için kaynak ayrıl"ması, 2012-2016 Planı için de korunmaktadır. Aynı şekilde, "mevcut tesisler aktif hale getirilecektir" ibaresi "sosyal tesisler ...daha etkin hale getirilecektir" biçiminde değiştirilerek korunmaktadır. 2007-2011 Planında sosyal faaliyetlerin arttırılacağı belirtilmişken, 2012-2016 Planında aynı vurgu korunmaktadır. Bu hedef kapsaminda 2012-2016 Planında, ek olarak eğitim vurgusunun ön plana çıkarıldığı görülmektedir. Bir başka anlatımla, beş yıl önceye göre bu hedef bağlaminda ilerleme kaydedilmediği ya da sinırlı kaydedildiği belirtilebilir.

Kurumsal kapasite ile ilişkili bir başka tespitte 2007-2011 Planı'nda yer alan "2007-2011 yılları arasında mevcut tüm tesislerin bakım ve onarım hizmetleri tamamlanarak idare binalarının her türlü eksikliği giderilmiş olacaktır" hedefinin gerçekleşme durumudur. 2012-2016 Planında bu hedefin personel ve ödenek yetersizliği nedeniyle gerçekleştirilemediği belirtilmektedir (KGM, tarihsiz f: 87).

Planın sonuç kısmının son cümlesi konu bağlamında önemlidir; "2012-2016 Stratejik Plan ile daha güçlü kurumsal bir yapıya kavuşma" umut edilmektedir (KGM, tarihsiz f: 89). Bu noktada planların uygulanma derecesinin planın kendisinden önemli olduğunu belirtmek yerindedir. 


\subsubsection{7-2021 Stratejik Plan1}

KGM Plan döneminde Ulaştırma, Denizcilik ve Haberleşme Bakanlığına bağlı, kamu tüzel kişiliğine sahip özel bütçeli bir kuruluştur.

Planda önceki Stratejik Planın (2012-2016) değerlendirmesi bulunmaktadır; buna göre, performans göstergelerinden sekizinin ölçülebilirlik kriterini karşılamadığ1 belirtilmektedir. 2017-2021 Plan çalışmalarında göstergelerin ölçülebilir olmasına özen gösterildiği belirtilmektedir (KGM, tarihsiz e: 18). 2013 ve 2014 yılları için performans hedeflerinin $\% 78$ 'inde hedef değerlere ulaşıldığı ya da aşıldığı, \%22'sinde ise hedef değerlere ulaşılamadığı belirlenmiştir. 2015 y1l sonunda ise performans hedeflerinin \%64'ünde hedef değerlere ulaşıldığı ya da aşıldığı, \%36'sında ise hedef değerlerinin altında kalındığ ${ }_{1}$ belirtilmektedir (KGM, tarihsiz e: 18).

Stratejik Plan (2017-2021) çalışmalarının üst politika belgeleri ile uyumlu olduğu belirtilmekle birlikte Türkiye Cumhuriyeti İklim Değişikliği Eylem Planında yer alan (2011-2023) “yol kaplamasında Bitümlü Sıcak Karışım yerine Ilık Karışım Asfalt kullanılarak sera gazı emisyonlarının sınırlandırılması" (Çevre Şehircilik Bakanlığı, 2012: 68) belirlemesinin aksine Stratejik Plan yol kaplamasında Bitümlü Sıcak Karışımı ${ }^{22}$ öngörmektedir (KGM, tarihsiz e: 26, 55).

Kurumsal kapasite bileşenlerine göre incelendiğinde şu tespitler yapılabilir;

Mali açıdan önceki Planlardaki sorunların devam ettiği görülmektedir;

Kuruluşumuza tahsis edilen sene başı yatırım bütçesi, yatırım amaçlı kullanılan cari bütçe de (bitüm alımı, yol bakım - onarımı, akaryakıt alımı ödenekleri) dahil olmakla birlikte, ihtiyaçları karşılamakta yetersiz kalmaktadır (KGM, tarihsiz e: 42).

\footnotetext{
22Diğer üst politika belgelerinde de, örneğin 11. Kalkınma Planında Bitümlü Sıcak Karışım kullanımı öngörülmektedir (Cumhurbaşkanlığı Strateji ve Bütçe Başkanlığı, 2019a: 75, 125-127). 2020 Yilı Cumhurbaşkanlığı Yıllık Programında da karayollarında ağır taşıt trafiği güzergâhlarında Bitümlü Sıcak Karışıma ağırlık verileceği belirtilmektedir (Cumhurbaşkanlığı Strateji ve Bütçe Başkanlığı, 2019b: 239).
} 
Sene başı yatırım bütçesi ile sene sonu bütçesinin çok farklı gerçekleşmesi nedeniyle alternatif Çalışma Programı yapmak, Performans Programına dâhil etmek ve Performans Programının içeriğinde yeniden düzenlemeler yapmak gereği doğmaktadır. Sene içinde kullanılacak bütçenin 2023 hedefleri dikkate alınarak sene başında ihtiyaçları karşılayacak miktarlarda tahsis edilmesi durumunda sağlıklı hedef belirleme, izleme ve değerlendirme imkânı olacaktır (KGM, tarihsiz e: 43).

Kuruluşun mülkiyetindeki taşıtların mevcut durumları ile ihtiyaçları karşılayabilecek durumda olmadığı belirtilmektedir (KGM, tarihsiz e: 52).

Makine parkının 16 yaş ve üstü oranının \%42,8 olduğu belirtlmekte, bununla birlikte makine parkının yeterliliğine ilişkin bir değerlendirme yapılmamaktadır.

İnsan kaynaklarına ilişkin sorunlar da devam etmektedir; çok sayıda deneyimli ve yetenekli personelin özel sektörün daha iyi ekonomik şartlar sunması nedeni ile kurumdan ayrılarak özel sektöre geçtiği, bu nedenle yetişmiş ve nitelikli eleman sıkıntısı yaşandığı belirtilmektedir.

KGM faaliyetlerinin zamaninda ve belirlenen standartlarda yapılması ile bakım-onarım çalışmalarının aksamaması için merkez ve taşrayı kapsayan personel şemalarına göre personel açığının nitelikli ve sürekli kadrolu eleman temini ile acilen giderilmesi gerekmektedir (KGM, tarihsiz e: 41).

İhale edilen işlerin yapım kontrollük hizmetlerinin mevcut personel ile karşılanamaması nedeniyle, müşavirlik hizmetlerinin hizmet satın alınarak yürütüldüğü ancak, müşavirlik firmalarında nitelikli personel istihdamında yaşanan sorunlar ve müşavir firma çalışanlarının kamu görevi yürüten personel sorumluluğunu taşımamaları nedeniyle istenilen verimin alınamadığ ${ }_{1}$ belirtilmektedir. Planda müşavirlik hizmetlerine ayrilan kaynaklarla daha fazla sayıda kadrolu personel çalıştırılmasının mümkün olduğu, bu nedenle kadrolu teknik personel istihdamına bir an önce geçilmesi gerektiği belirtilmektedir (KGM, tarihsiz e: 41). 
İnsan kaynakları bağlamında; "personel ve ücret politikalarının iyileştirilmesinin doğru bir çözüm olacağı açıtır" tespiti kurumsal kapasite bağlamında önemlidir (KGM, tarihsiz e: 41).

Kurum çalışanlarının memnuniyet ve bağlılık düzeylerinin araştırıldığı çalışan memnuniyeti anketine göreli olarak düşük $(\% 58,4)$ katılım sağlanmıştır. Ankete katılanların \%66,8'i kurumdaki çalışma istekleri ile motivasyonlarını "normal ve üzeri" olarak değerlendirirken, \% 59,9'u KGM'de çalışmaktan genel olarak memnun olduklarını belirtmiştir. Araştırma kapsamında KGM personelinin çalışma hayatına ilişkin genel memnuniyet ortalaması 100 üzerinden 52,6 olarak hesaplanmıştır (KGM, tarihsiz e: 30 ).

Araştırmaya katılanlar kamu sektöründe benzer işi yapan çalışanlara göre aldıkları ücretten memnun değildir. Kurum içi ücret dağılımı da adaletli bulunmamakta, ayrıca sosyal etkinliklerin yeterli olmadığını düşünülmektedir. Kurum içi kariyer planlaması yapılamaması çalışanların memnuniyetsiz olduğu bir diğer konudur (KGM, tarihsiz e: 31$)^{23}$.

Araştırma sonucunda KGM'nin genel çalışan bağlılığ1 100 üzerinden 52,3 olarak tespit edilmiştir. Bu değer KGM tarafından "bağl1lığ1 düşük" olarak değerlendirilmektedir (KGM, tarihsiz e: 31).

Dış paydaşlar açısından memnuniyet düzeyi de ortalama olarak 59'dur (KGM, tarihsiz e: 33). Dış paydaş analizine göre; öncelikli düzeltme alanı "çalışanların çözüm üretmeleri" konusudur (KGM, tarihsiz e: 33).

Bir önceki Planda var olan kurum kültürü başlığı bir ölçüde genişletilmiş; "Karayolculuk Ruhu" kavramı korunmuştur. ${ }^{24}$ Kurum kültürüne daha önceki Planlarda belirtilmeyen üç özellik eklenmiştir; 1. İletişimin, en alt düzeydeki çalışanı ile en üst düzeydeki yöneticisi

23 Araştırma kapsamında çalışanlarının çalışma ortamı ve koşullarından memnun oldukları, yaptıkları işi kurum hizmetleri açısından önemli buldukları ve benimsedikleri, işlerini yaparken yeni şeyler öğrendikleri, kurum içi bilgi akışı, iletişim ve işbirliğinden ortalamanın üzerinde memnuniyet duydukları saptanmıştır (KGM, tarihsiz e: 31).

24 Üretilen hizmet ve yapılan eserlerin gururunu paylaşarak, bütün çalışanların birbirine ve kuruma gönül bağıyla bağlanması, "Karayolculuk Ruhu" kavramıla ifade edilmiştir (KGM, tarihsiz e: 39). 
arasında, saygıda eksiklik olmadan sağlanması, 2. Yöneticilerin sorunlara hızlı, yapıcı yönde çözüm getirici yaklaşması, 3. Çalışanların yurda ve millete hizmeti her şeyin önünde tutması.

Aidiyete ilişkin olarak kurumun okul gibi işlev gördüğü belirtilmektedir;

KGM kuruluşundan bu yana, faaliyet alanlarındaki ulusal ve uluslararası gelişmeleri izleyerek, seminer, sempozyum gibi çalışmalara katılım sağlayarak çalışanları için bir okul görevi görmekte, aynı meslek grubundan personel veya aynı işleri yapan çalışanlar arasında olumlu bağlar kurulmasını ve kurumsal aidiyetin gelişmesini sağlamaktadır (KGM, tarihsiz: 39).

Kurum kültürü ve diğer kurumsal kapasite bileşenleri açısından önemli olan "kurumsal hafıza" bu Planda ilk kez vurgulanmaktadır. KGM hizmetlerinin yürütülmesinde mevzuat, mesleki değerler ile kurumsal ilkelerin yanı sıra kurumsal hafızanın da temel alındığı belirtilmektedir.

2012-2016 Planının GZFT analizinde zayıf yan olarak belirtilen "halkla ilişkiler" konusunda, 2017-2021 Planında "basın ve halkla ilişkiler çalışmaları ile kamuya çalışmaları hakkında sürekli bilgi aktararak şeffaf bir kurum olmaya çaba göster"ildiği vurgulanmaktadir.

Kurumsal kapasite bağlamında teknoloji kullanımı KGM'nin görece güçlü olduğu bir yandır. Bu konu Planda "bilgisayarın yıllardan beri ve yaygın kullanımı ile bilgi iletişim faaliyetlerinin daha kısa sürede gerçekleştirilmesi, bilgiye erişim kolaylığı, KGM merkez ve taşra birimleri arasında bilgi iletişimi, verimliliğin ve koordinasyonunun arttırılması sağlanmıştır" (KGM, tarihsiz e: 47) biçiminde yer almaktadır.

Planda KGM'nin amaçlarından dördüncüsü "kurumsal kapasiteyi geliştirmek" olarak belirlenmiştir. Bu başlık altında dört hedef bulunmaktadır (KGM, tarihsiz e: $76 \mathrm{vd}$.): 1 . Kuruluşun araştırma ve geliştirme konularındaki altyapı, ekipman ve laboratuarları iyileştirilecek ve idari kapasite artırılacaktır. 2. Bilgi iletişim altyapısından yararlanılarak karar destek ve yönetim sistemleri 
geliştirilecek, etkin kullanımları sağlanacaktır. 3. Kurum personelinin çalışma şartlarının, bilgi birikiminin iyileştirilmesi ve mesleki memnuniyetinin arttırılması sağlanacaktır. 4. Trafik ve ulaşım bilgilerinin zamanında, güvenilir ve sürekli olarak elde edilmesine ilişkin çalışmalar yapılacaktır.

Bu hedeflerin gerçekleşmesine yönelik risklerden bazıları şunlardır: 1. Personelin ücret politikası nedeniyle işten ayrılması. 2. Uygun eğiticilerin bulunamaması nedeniyle eğitimlerin iptal edilmesi. 3 . Personel yetersizliği ve iş yoğunluğu nedeniyle eğitimlerin verilememesi. 4. Personelin mazeretleri nedeniyle planlanan eğitimlerin daha az katılım ile gerçekleşmesi. 5. İhale sürecinin uzaması nedeniyle cihazların geç teslim alınması, zamanında temin edilememesi. 6. Uluslararası konferans ve seminerlere yeterli katılım sağlanamaması, Dünyadaki gelişmelerin takip edilememesi ve ülkemize getirilememesi. 7. Araştırma ve geliştirme yapan personele maddi destek verilememesi nedeniyle yeteri kadar araştırma geliştirme projesi üretilememesi. 8. Yurtdışı yabancı dil eğitimi, yüksek lisans ve doktora programlarına katılımın teşvik edilmemesi nedeniyle yeni metot, malzeme ve teknolojilerin takip edilememesi. 9 . Koordinasyonlu işlerde yaşanabilecek sorunlar, proje süresinin uzaması 10. Projelerde görevlendirecek yetkin personel temin edilememesi. 11. Eğitilmiş personel sıkıntısı yaşanması.

Hedeflerin gerçekleştirilmesi için temel stratejiler insan kaynaklarına ve eğitime daha fazla kaynak ayrılarak kurum içi ve dışı eğitime ağırlık verilmesi ile servis, yemek, kültürel-sosyal etkinlikler, misafirhane hizmetleri gibi sosyal olanakların hizmet seviyesi ve kalitesinin arttırılmasıdır (KGM, tarihsiz e: 92).

Planda belirlenen amaçların kurumsal kapasite ile ilişkili boyutları olmasının da etkisiyle amaçlara yönelik hedeflerin zaman zaman iç içe geçebildiği ya da çakıştığı görülmektedir.

Belirlenen amaçlar altındaki hedefler zaman zaman birden fazla farklı amaca hizmet edebilmektedir. Hedeflerde yer yer çakışmalar olsa da iç içe girmeler de görülebilmekle birlikte hedefler, en uygun ve en çok hizmet ettiği amaç altında toplanmaya gayret gösterilmiştir (KGM, tarihsiz e: 76). 
Kurumsal kapasite bağlamında hedeflerin iç içe geçmesi saptaması önemlidir. Örneğin karayolu kaynaklı çevresel etkilerin azaltılması amacına yönelik belirlenen hedefler, kurumsal kapasiteyi güçlendirici etkinlikler içermektedir. Planda belirtildiği üzere (KGM tarihsiz e: 76), çevresel etkilerin azaltılması amacının gerçekleştirilmesi için yeterli sayı ve nitelikte insana, teknolojik kaynaklara ve mali imkanlara olan ihtiyaç açıktır. Bu nedenle amaçlara ilişkin hedeflerde çakışmalar doğması olağandır. Aynı biçimde yine beşinci amaç olan karayolu kaynaklı çevresel etkilerin azaltılması için belirtilen riskler ile kurumsal kapasite amacı için belirtilen riskler de kesişmektedir; "maddi destek sağlanamaması nedeniyle yeteri kadar araştırma geliştirme projesi üretilememesi”, “ ...yeterli sayıda teknik ve yetişmiş personelin bulunmaması", "yeterli ödenek ve personel temin edilememesi" (KGM tarihsiz e: 96) saptamaları örnek gösterilebilir.

Önceki Plan'da olduğu gibi, daha güçlü bir kurumsal yapıya kavuşma umuduna yapılan vurgu, bu Plan'ın sonuç kısmında da bulunmaktadır (KGM, tarihsiz e: 109).

2017-2021 Stratejik Planına ilişkin olarak Sayıştay herhangi bir denetim bulgusu tespit etmemiştir (Sayıştay, 2019: 160).

\subsubsection{9-2023 Stratejik Plan1}

Bu plan döneminde KGM, 4 No'lu Cumhurbaşkanlığ1 Kararnamesi doğrultusunda, Ulaştırma ve Altyapı Bakanlığına bağlı tüzel kişiliği olan özel bütçeli bir kuruluş olarak yeniden yapılandırılmıştır (KGM, tarihsiz a: 18).

Cumhurbaşkanlığı Hükümet Sistemine geçişle birlikte yürürlükteki stratejik planın süresi dolmadan yeni bir stratejik plan hazırlanmasına karar verilmiştir (KGM, tarihsiz a: 9). Yeniden hazırlamaktan çok gözden geçirme, revize etme söz konusudur. Örnek vermek gerekirse önceki planda iki ayrı değer olarak verilen "kariyer planlamasına önem verme" ile "Karayolculuk Ruhu" bu planda tek bir temel değer olarak yer almaktadır (KGM, tarihsiz a: 11). ${ }^{25}$ İkinci bir örnek

25 Planda bu değer (Kariyer Planlamasına Önem Vererek Karayolculuk Ruhunu Korumak); "personelin çalışma koşullarını ve sosyal yaşam standartlarını iyileştirmek, kurum içi iletişimi açı tutmak, kurum kültürüne sahip çıkmak, etik 
kurumsal kapasite amacına ilişkindir. Önceki planda bu amaç için dört temel hedef saptanmışken bu planda hedeflerden biri elenerek, önceki Plandaki üç temel hedef korunmuştur (KGM, tarihsiz a: 11). Ayrıca 2017-2021 Stratejik Planında yer alan performans göstergelerinden ölçülebilirlik kriterlerini karşılamayan performans göstergeleri, yeni Planda revize edilmiştir (KGM, tarihsiz a: 18).

Plan kurumsal kapasite bileşenlerine göre incelendiğinde şu tespitler yapılabilir;

Ulaştırma sektörü için ayrılan bütçe ödeneklerinden karayolu için yapılan tahsislerde 2000'li yıllarda başlayan artış eğilimine (KGM, tarihsiz a: 31) rağmen kuruma tahsis edilen sene başı yatırım bütçesi ve yatırım amaçlı kullanılan cari bütçenin ihtiyaçları karşılamakta yetersiz kalmayı sürdürdüğü belirtilmektedir (KGM, tarihsiz a: 32). Sene içinde kullanılacak bütçenin plan dönemi (2023) hedefleri dikkate alınarak "sene başında ihtiyaçları karşılayacak miktarlarda tahsis edilmesi durumunda sağlıklı hedef belirleme, izleme ve değerlendirme imkanı olacaktır" denmektedir (KGM, tarihsiz a: 33). Bir başka anlatımla, tahsis edilen bütçe ile iş yükü arasındaki oransızlığa vurgu sürmektedir. Makine parkında göreli iyileşmeye (bkz Şekil. 2) rağmen 26 Planda "ekonomik ömrü dolan ve yenilenemeyen makine parkının yetersiz kalması" ve "mevcut yenileme ve dengeleme projelerine makine alımı için yeterli ödenek temin edilememesi" (KGM, tarihsiz a: 72) tespitleri bulunmaktadir. Ayrıca kurumun mülkiyetindeki taşıtların mevcut durumları ile ihtiyaçları karşılayabilecek nitelikte olmadığı vurgulanmaya devam etmektedir (KGM, tarihsiz a: 36$)^{27}$.

\footnotetext{
değerlere bağlı olmak" olarak açıklanmaktadır (KGM, tarihsiz a: 53). Bu açılama önceki planda belirtilen iki ayrı açıklamanın birleştirilmesinden oluşturulmuştur.

262019 yılı faaliyet raporunda da makine parkındaki iyileşme vurgulanmaktadır (KGM, tarihsiz b: 20).

272019 y1lı faaliyet raporunda kuruma ait taşıtlara olan ihtiyaç vurgulanmaktadır (KGM, tarihsiz b: 20).
} 
Tablo 2: Stratejik Plan Dönemlerine Göre Makine Parkının Durumu

\begin{tabular}{|c|c|}
\hline Strateji Planlar & 16 yaş ve üzeri makine park1 \\
\hline $2007-2011$ & $\% 52.5$ \\
\hline $2012-2016$ & $\% 42.8$ \\
\hline $2017-2021$ & $\% 37.4$ \\
\hline $2019-2023$ & \\
\hline
\end{tabular}

İnsan kaynakları açısında değerlendirme yapıldığında 2017-2019 Planındaki vurgular aynen korunmaktadır;

Çalışmakta olan deneyimli ve yetenekli personele özel sektörün daha iyi ekonomik şartlar sunması nedeni ile çok sayıda personel kurumdan ayrılarak özel sektöre geçmektedir. Bu nedenle yetişmiş eleman sıkıntısı yaşanmaktadır...personel açığının nitelikli eleman temini ile acilen giderilmesi gerekmektedir (KGM, tarihsiz a: 31).

İhale edilen işlerin yapım kontrollük hizmetlerinin mevcut personel ile karşılanamaması neticesinde, müşavirlik hizmetleri satın alınarak yürütülmektedir. Ancak, müşavirlik firmalarında nitelikli personel istihdaminda yaşanan sorunlar ve müşavir firma çalışanlarının kamu görevi yürüten personel sorumluluğunu taşımamaları nedeniyle istenilen verim alınamamaktadır. Müşavirlik hizmetlerine ayrılan kaynakların karşılığında daha fazla personelin çalıştırılması mümkün olduğundan KGM bünyesindeki personel istihdamının artırılmasının uygun olacağ değerlendirilmektedir (KGM, tarihsiz a: 31).

Planda personelin motivasyonunu, istihdamın sürekliliğini ve kurumun tercih edilirliğini artıracak unsurlar önerilmektedir (KGM, tarihsiz a: 31).

Paydaş Analizi için yapılan ankete \%59,4 oranında katılım sağlanmıştır (KGM, tarihsiz a: 24). Ankete katılanların yaklaşık \%78,8'i KGM'deki çalışma istekleri ile motivasyonlarını normal ve üzeri olarak değerlendirirken, \%76,8'i KGM'de çalışmaktan genel olarak memnun olduklarını belirtmiştir. Araştırmaya katılanların yaklaşık $\% 60$ '1 KGM'yi bir aile, kendini de bu ailenin bir ferdi olarak gördüğünü ifade etmiştir. KGM personelinin çalışma hayatına ilişkin genel 
memnuniyet ortalaması 100 üzerinden değerlendirildiğinde 55,8 olarak hesaplanmıştır.

Dış paydaş analizine göre; "yeterli sayıda uzman personel bulun"maması öncelikli ele alınması gereken durumdur (KGM, tarihsiz a: 25).

Kurum kültürü bağlamında 2017-2019 Planındaki saptama ve vurgular (çalışanlar için bir okul görevi görme; kurumsal hafıza) aynen korunmaktadır (KGM, tarihsiz a: 30).

Kurumsal kapasite bağlamında teknoloji ve bilişim altyapısı göreli olarak güçlü bir alandır (KGM, tarihsiz a: 30, 50-51).

Amaçların gerçekleştirilmesine yönelik riskler incelendiğinde 20172019 Planı ile büyük ölçüde benzerlik (örneğin uzman personel istihdamında sürekliliğin sağlanamaması; yeterli ödeneğin sene başında sağlanamaması; eğitim eksikliği; paydaşlarla yeterli koordinasyon sağlanamaması 28 ; uzman personel istihdamında sürekliliğin sağlanamaması; teknik ekipman eksikliği; planlanan eğitimlere personelin iş yoğunluğu sebebiyle katılım sağlayamaması) olmakla birlikte önceki Planlarda açıkça belirtilmeyen riskler de (örneğin yapım öncesi proje hazırlı sürecine yeterli zaman ayrılamaması; yapım sırasında karşılaşılacak problemlerin önüne geçilebilmesi için projelendirme aşamasında gerekli sürenin ayrılamaması; projelerin önceliklendirilmemesi) bulunmaktadır (KGM, tarihsiz a: 61).

KGM, amaçlarını gerçekleştirilebilmek açısından temel ihtiyaçlarını saptamıştır. Bu ihtiyaçların büyük çoğunluğu doğrudan kurumsal kapasitenin bileşenleri ile ilişkilidir. Örneğin özlük haklarında yapılabilecek iyileştirmeler ile kurum personelinin memnuniyetinin artırılması, personelin bilgi birikiminin iyileştirilmesine yönelik eğitimler düzenlenmesi, yeni teknolojilerin takibi ve kurumda uygulanmasına yönelik bütçe tahsisi, hedefler ile bütçe kaynakları arasındaki dengenin sağlanması, kaynak planlaması ile bütçe

28 11. Kalkınma Planı Ulaştırma Özel İhtisas Komisyonu Raporunda karayolu sektörüne yönelik GZFT analizinde "kurumlar arası görev ve yetki çatışmasının" bulunduğu, ayrıca koordinasyon eksikliği belirtilmektedir (Kalkınma Bakanlığı, 2018b: 31). 
programlamasının etkin yapılması, paydaşlar ile koordinasyonun sağlanması çalışmalarına önem verilmesi ve projelendirme aşamasında detaylı çalışmaların yapılmasına önem verilmesi temel ihtiyaçların başlıcalarıdır. İhtiyaçlar bir bütün olarak incelendiğinde kurumsal kapasitenin tüm bileşenler düzeyinde arttırılmasının gerekliliği ortaya çıkmaktadır. Diğer yandan tespitlerin yaşama geçirilmesi durumunda kurumsal kapasitenin artacağı görülmektedir.

2017-2019 Planında olduğu gibi, kurumsal kapasite bağlamında hedefler iç içe geçmektedir. Örneğin karayolu kaynaklı çevresel etkileri azaltma amacının riski "KGM personeline yönelik maddi teşviklerin olmaması" olarak belirtilemektedir. Bu risk kurumsal kapasite ile doğrudan ilişkilidir (KGM, tarihsiz a: 83).

2019-2023 Strateji Planının GZFT analizi kısmındaki zayıf yanlar incelendiğinde önceki planda olmayan ancak 2012-2016 Planında vurgulanan bir unsura ("personelin kurumsal sorumluluklarına dair karşılaştıkları hukuksal sıkıntılarda kurumdan yeterli destek bulamaması") yeniden yer verildiği görülmektedir. Bu ekleme kurumsal kapasitenin geliştirilmesi ihtiyacının sürmekte olduğunun bir başka göstergesidir.

Sonuç olarak geçmiş Planlarda kurumsal kapasite bağlamında tespit edilen eksiklikler 2019-2023 Planında önemli ölçüde varlığını sürdürmektedir. Son bir örnek daha vermek gerekirse "kuruluşun halkın projelere katılımına ve görüşlerine yeterince önem vermeyişi" tespiti bütün Planlarda KGM'nin zayıf yanlardan biri olarak varlığını sürdürmektedir.

\section{Değerlendirme ve Sonuç}

Son yıllarda kurumsal kapasite konusu kamu yönetimi alanında görece önemli hale gelmiştir. Türkiye' de 5018 sayılı Kanun ile birlikte gündeme gelen stratejik planlama kamu idarelerinin kurumsal kapasitelerine ilişkin önemli veriler içermektedir.

KGM'nin dört stratejik planı, 2019 faaliyet raporu, 2020 performans programı ve 2018 Sayıştay denetim raporu birlikte değerlendirildiğinde, KGM'nin kurumsal kapasite bağlamında örgüt yapısı, yetki devri ve yönetim bilgi sistemi alanlarında güçlü olduğu 
görülmektedir. Bununla birlikte, kurumsal kapasiteye ilişkin darboğazlar da bulunmaktadır. Örneğin koordinasyon ve kaynak sorunu dikkat çekicidir.

Genel olarak değerlendirildiğinde stratejik planlama çalışmalarının KGM'nin kurumsal kapasitesine ilişkin sorunlarını ortaya koyduğu ancak sorunların aşılmasına, kapasitenin geliştirilmesine yeterli katkısının olmadığı görülmektedir. Bütçe kısıtı, nitelikli insan kaynağı temin etme, nitelikli insan kaynağının sürekliliğini ve motivasyonunu sağlama açısından yaşanan sorunlarla örgütün kaynakları ile orantılı olmayan iş yükü, kapasitenin geliştirilmesinin önündeki engellerdir.

Literatürdeki kurumsal kapasite tanımlarından hangisi benimsenirse benimsensin KGM'nin kısmen başarılı olduğu görülmektedir. Yaşadığı sorunları tanımlamada görece başarılı olsa da, sorunlara çözüm üretmede sağladığı başarı kısmidir. Hedefler belirleyebilmekte bununla birlikte hedefleri bir ölçüde yaşama geçirebilmektedir. Hedeflere ulaşmada araç/güç eksiği bulunmaktadır. Kurumsal kapasitenin bileşenleri açısından bakıldığında kimi bileşenler, örneğin teknolojik kaynaklar görece iyi durumda bulunsa da hızlı teknolojik değişim nedeniyle bu durumun sürdürülebilirliği de risk faktörüdür. Öte yandan, her stratejik planda ve faaliyet raporunda vurgulanan "Karayolculuk Ruhu" kavramı kurumun kendi anket sonuçlarında ortaya çıkan iç paydaşların düşük bağlılık düzeyi ile bağdaşmamaktadır.

2017-2021 Planında kurum kültürüne eklenen ve 2019-2023 Planında korunan özelliklerin (örneğin yöneticilerin sorunlara hızlı, yapıcı yönde çözüm getirici yaklaşması özelliğinin) kurumsal kapasiteye etkisinin zaman içinde izlenmesi gereklidir. Bu özelliğin yaşama aktarılmasının kurumun etkili ve verimli hizmet sunumuna katkısı olacağı açıktır. Aksi halde özlü bir söz olarak raporlarda yaşayacak ancak gerçek hayatta işlerliği olmayacaktır.

Önümüzdeki yıllarda iç ve diş nedenlerle ulaştırmada karayolu ağırlıklı politika sürdürülecektir. Bu nedenle karayolu hizmetinin niteliğinin artırılması için KGM'nin kurumsal kapasitesinin geliştirilmesine yönelik çabalara yenilerinin eklenerek sürdürülmesi önem taşımaktadır. 


\section{Kaynakça}

Addison, H. J. (2009). Is administrative capacity a useful concept? Review of the application, meaning and observation of administrative capacity in political science literature. LSE Research

http://personal.lse.ac.uk/addisonh/Papers/AC_Concept.pdf [Erişim tarihi: 7 Temmuz 2020].

Çakar, A., \& Bayrakçı, Ö. (2016). Ulaşım ve Trafik Politikalarında Planlama Gerekliliği Oda Raporu. TMMOB Makina Mühendisleri Odası.

Çevre Şehircilik Bakanlığı (2012). İklim Değişikliği Ulusal Eylem Planı 2011-2023.

Çolak, E. (2019). İdari Kapasite: Teorik ve Güncel Tartışmalar. (Yayımlanmamış Yüksek Lisans Tezi). Hacettepe Üniversitesi SBE, Ankara.

Güven, H.S. (1982). Türkiye'de Ulaşım Sistemi ve Karayolu Ulaştırma Kooperatifleri. TODAİE, Sevinç.

Kalkınma Bakanlığı (2018a). Kamu İdareleri İçin Stratejik Planlama Kılavuzu (3. sürüm).

Kalkınma Bakanlığı (2018b). 11. Kalkınma Planı (2019-2023) Ulaştırma Özel İhtisas Komisyonu Raporu. Ankara.

Kamu İdarelerinde Stratejik Planlamaya İlişkin Usul Ve Esaslar Hakkında Yönetmelik (2018)

Karayolları Genel Müdürlüğü (KGM) (2007). 2006 Yılı Faaliyet Raporu. Strateji Geliştirme Dairesi Başkanlığı.

Karayolları Genel Müdürlüğü (KGM) (2008). 2007 Yılı Faaliyet Raporu. Strateji Geliştirme Dairesi Başkanlığı.

Karayolları Genel Müdürlüğü (KGM) (2015). 2015 yılı Kurum İdare Kurulu Toplantı

Tutanağı,http://www.bms.org.tr/Sayfa/karayollari-genelmudurlugu-kurum-idari-kurul-toplantisi-yapildi-204.html [Erişim tarihi: 5 Temmuz 2020]. 
Karayolları Genel Müdürlüğü (KGM) (2016). 2011-2015 Yilları Arası Devlet ve Il Yollan Bakım İşletme Harcamalarn Analizi. Strateji Geliştirme Dairesi Başkanlığı Ulaştırma Maliyetleri ve Verimlilik Şubesi Müdürlüğü.

Karayolları Genel Müdürlüğü (KGM) (2017). 2017 yılı Kurum İdare Kurulu Toplant Tutană̆g.

http://www.bms.org.tr/Content/upload/files/ 636559482222 001467.pdf [Erişim tarihi: 5 Temmuz 2020].

Karayolları Genel Müdürlüğü (KGM) (2020). 2020 Performans Programı. Strateji Geliştirme Dairesi Başkanlığ1

Karayolları Genel Müdürlüğü (KGM) (tarihsiz a). 2019-2023 Stratejik Planı. Strateji Geliştirme Dairesi Başkanlığı.

Karayolları Genel Müdürlüğü (KGM) (tarihsiz b). 2019 Yılı Faaliyet Raporu. Strateji Geliştirme Dairesi Başkanlığı.

Karayolları Genel Müdürlüğü (KGM) (tarihsiz c). 2018 Yılı Faaliyet Raporu. Strateji Geliştirme Dairesi Başkanlığı.

Karayolları Genel Müdürlüğü (KGM) (tarihsiz d). 2017 Yılı Faaliyet Raporu. Strateji Geliştirme Dairesi Başkanlığı.

Karayolları Genel Müdürlüğü (KGM) (tarihsiz e). 2017-2021 Stratejik Planı. Strateji Geliştirme Dairesi Başkanlığı.

Karayolları Genel Müdürlüğü (KGM) (tarihsiz f). 2012-2016 Stratejik Planı. Strateji Geliştirme Dairesi Başkanlığı.

Karayolları Genel Müdürlüğü (KGM) (tarihsiz g). 2007-2011 Stratejik Planı.

Kocaoğlu, B.U. (2019). Kamu kurumlarında yönetsel kapasitenin güçlendirilmesi. Sayıştay Dergisi, 114, 117-133.

Kurşunlu, E. (2004). Avrupa Birliği Müktesebatının Uygulanması Çerçevesinde İdari Kapasite. (Uzmanlık Tezi). Avrupa Birliği Genel Sekreterliği, Ankara.

Kutlu, Ö. (2012). Selçuklu Belediyesi Kurumsal Kapasite Geliştirme Çalışması Raporu. Selçuklu Belediyesi. 
Kutlu, Ö. (2013). Yerel Yönetimlerde Kurumsal Kapasite Geliştirme Çalışmaları. E. İsbir (Ed.) Kamu Yönetiminde Değişim ve Güncel Sorunlar. Ankara: TODAİE, 459-487.

Matachi, A. (2006). Capacity Building Framework. UNESCO-IICBA, Ethiopia, Addis Ababa.

OECD, (2011). Assessment Turkey 2011, https:/ / www.ab.gov.tr/files/ EKYB/sigma/assessment_turkey_2011.pdf [Erişim tarihi: 7 Temmuz 2020].

Pollitt, C., \& Bouckaert G. (2002). Public Management Reform: A Comparative Analysis. Oxford University Press.

Sayıştay (2019). Karayolları Genel Müdürlü̆̆̈̈ 2018 Yılı Sayıştay Denetim Raporu. Ankara.

Tekeli, İ. (2010). İstanbul Ve Ankara İçin Kent İçi Ulaşım Tarihi Yazıları. İstanbul: Tarih Vakfi.

Ulusal Program (2001). Avrupa Birliği Müktesebatının Üstlenilmesine İlişkin Türkiye Ulusal Programı. 2001 Yılı Ulusal Programı. https://www.ab.gov.tr/_196.html [Erişim tarihi: 5 Temmuz 2020].

Ulusal Program (2003). Avrupa Birliği Müktesebatının Üstlenilmesine İlişkin Türkiye Ulusal Programı. 2003 Y1lı Ulusal Programı. https://www.ab.gov.tr/_196.html [Erişim tarihi: 5 Temmuz 2020].

United Nations Development Programme (UNDP) (2009). Capacity Development: A UNDP Primer, USA, New York.

Van Bork, G. (2014). Developing Administrative Capacities, European Commission, https://ec.europa.eu/regional_policy/sources/docgener/inf ormat/expert_training/admin_capacity_en.pdf, Brussels. [Erişim tarihi: 5 Temmuz 2020].

Verheijen, A.J.G. (2000). Administrative Capacity Development A Race Against Time? Working Documents. Scientific Council for Government Policy. Hague. 
Yap1-Yol Sendikas1, (2010). http://www.yapiyolsen.net/index.php/ yapi-yol-sen-bildiriler/32-karayollari-ge-emekcler-olarak.html [Erişim tarihi: 2 Temmuz 2020].

5018 Sayılı Kamu Mali Yönetimi Ve Kontrol Kanunu (2003). 